\title{
A Content Analysis of the Portrayals of Female Journalists Before and After the Second-Wave Feminist Movement
}

Zachary King

Follow this and additional works at: https://researchrepository.wvu.edu/etd

\section{Recommended Citation}

King, Zachary, "A Content Analysis of the Portrayals of Female Journalists Before and After the SecondWave Feminist Movement" (2015). Graduate Theses, Dissertations, and Problem Reports. 5980. https://researchrepository.wvu.edu/etd/5980

This Thesis is protected by copyright and/or related rights. It has been brought to you by the The Research Repository @ WVU with permission from the rights-holder(s). You are free to use this Thesis in any way that is permitted by the copyright and related rights legislation that applies to your use. For other uses you must obtain permission from the rights-holder(s) directly, unless additional rights are indicated by a Creative Commons license in the record and/ or on the work itself. This Thesis has been accepted for inclusion in WVU Graduate Theses, Dissertations, and Problem Reports collection by an authorized administrator of The Research Repository @ WVU. For more information, please contact researchrepository@mail.wvu.edu. 
A Content Analysis of the Portrayals of Female Journalists

Before and After the Second-Wave Feminist Movement

\author{
Zachary King
}

Thesis submitted

to the Reed College of Media

at West Virginia University

in partial fulfillment of the requirements for the degree of

Master of Science in

Journalism

Steve Urbanski, Ph.D., Chair

Emily Corio, M.S.J.

April Johnston, M.F.A.

Anna Elfenbein, Ph.D.

Department of Journalism

Morgantown, WV

2015

Keywords: female journalists, second-wave feminist movement, film

C2015 Zachary King 


\section{Abstract \\ A Content Analysis of the Portrayals of Female Journalists \\ Before and After the Second-Wave Feminist Movement}

\section{Zachary King}

The purpose of this master's thesis is to investigate the possibility of a correlation between the portrayals of female journalists portrayed in films before and after the second-wave feminist movement. The study uses real-world factors to compare the characteristics of the portrayals of the female journalists. Two coders viewed eight films to determine possible correlations in the following: relationships status, whether the characters had children, whether the "sob sister" persona was portrayed, and the characters' career advancement (if any). 


\section{Table of Contents}

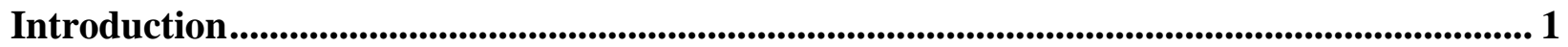

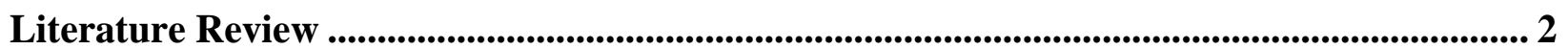

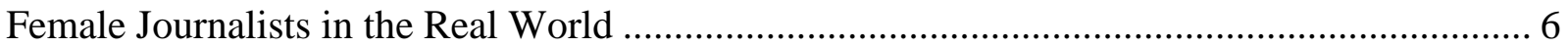

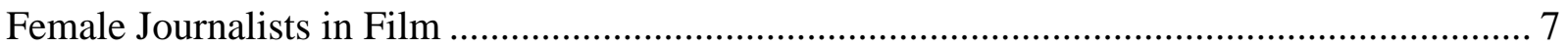

Research Questions..................................................................................................................................... 10

Methodology ...................................................................................................................................... 10

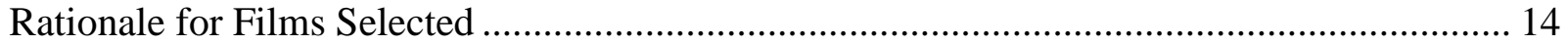

Real-World Factors to Be Considered ............................................................................. 15

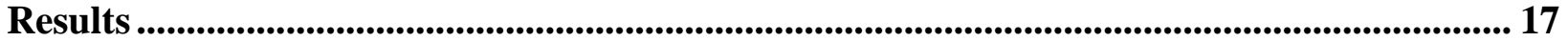

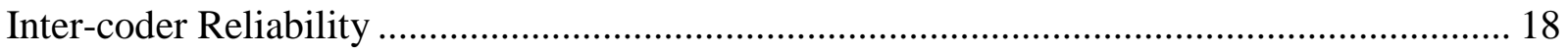

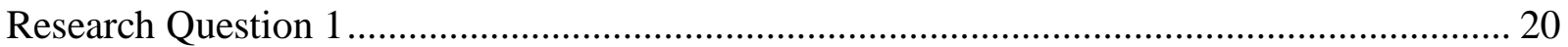

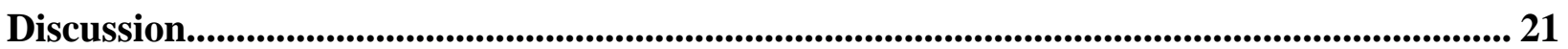

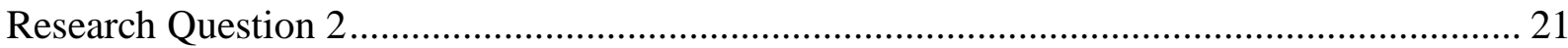

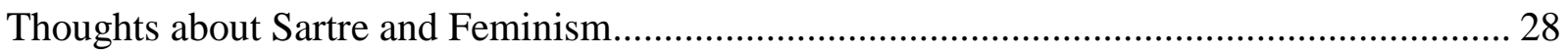

Expected Results and Implications _....................................................................................... 29

References............................................................................................................................................. 31

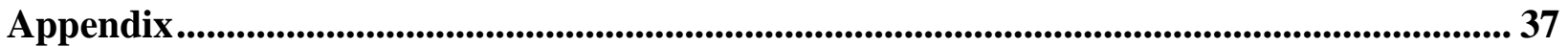




\section{Introduction}

Since the beginning of the $20^{\text {th }}$ century, stereotypes have been common in the portrayal of female journalists in American film. The following research is a descriptive study that will examine these stereotypes and suggest reasons why female characters have been portrayed with these stereotypes. Specifically, this research will focus on the portrayals of female journalists in American films before and after the second-wave feminist period, which included the women's movement. According to Gordon (2013), second-wave feminism was "the largest social movement in U.S. history" (p. 21). Gordon also stated that second-wave feminism lasted "from the mid-1960s to its decline in momentum in the 1980s" (p. 21). This research also will examine what has changed in the portrayals of these female journalists in American film before and after this period, as well.

This research is important because it will provide a new perspective on why female journalists are portrayed with these stereotypes in American film. The research will be conducted through a content analysis of an empirical nature in the hope of expanding the existing knowledge of the portrayals of female journalists in American film. This descriptive thesis will use Sartre's interpretation of the phenomenology theory to explain the similarities and differences of the characteristics of female journalists in American film before and after the second-wave feminist period in the United States.

Characters will be examined from the following eight films: Platinum Blonde; $M r$. Deeds Goes to Town; His Girl Friday; Woman of the Year; Superman; The China Syndrome; Absence of Malice; and Broadcast News. The main female journalist characters from these eight films will be compared and contrasted with the help of Sartre's interpretation of phenomenology 
to explain the aforementioned similarities and differences. These specific films were chosen because four were produced prior to the second-wave feminist period and the other four films were produced at the very end of it. The films are also considered "classics" by the definitions given by film experts, which will later be discussed. Eight films were chosen to provide a sizable sample of the films that were considered "classics" during the time periods that were examined.

\section{Literature Review}

The following literature review will analyze articles that discuss the patterns of characteristics of female journalists portrayed in American film before and after the second-wave feminist period and what elements make up the period. This is vital information that will facilitate the comprehension of how the characteristics of these specific female journalists portrayed in American film have changed or stayed the same before and after the period. The following information is also important to comprehend this transformation because this information expedited changes in the status of women in American society.

Grosz (1989) defined three different categories of feminism: liberal, Marxist, and radical (p. xi). She defines liberal feminism as “a feminism which seeks to attain women's equality with men" (p. xi). Marxist feminism is defined as "a position which seeks to integrate an understanding of the oppressed position of women within patriarchy into an understanding of other forms of domination" (p. xi). She says that radical feminism "seeks to understand women's oppression as women within patriarchy, without, however, relying on patriarchal or 
masculinist concepts" (p. xi). With this research focused on the second wave, Grosz's definition of liberal feminism fits best with the changes that took place during that period.

Women in the second-wave feminist movement called it by that name for several reasons, the first being that it helped the public remember "earlier movements for education, the vote, and other goals that most people in the 1960s would have considered women's self-evident rights" (Laughlin \& Castledine, 2012, p. ix). The phrase was also used "to strike a break with the past, to clarify what was new about their movement, and to lend urgency to their demands" (p. ix). Early second-wave feminists liked the phrase because "they believed that associating their activism with that of successful 'first wave' suffragists helped second wavers claim credibility at the same time that it inspired women to join their ranks" (p. 247). The first-wave feminist movement was mainly focused on suffrage and was largely defined by the passage of the $19^{\text {th }}$ Amendment in 1920, which gave women the right to vote. The American society is currently in the third wave of feminism, but it is difficult to categorize the period because many issues are yet to be created or resolved.

The main period of feminism that this paper is concerned with is the second wave. As stated above, Gordon (2013) said the second-wave feminist period began around the mid-1960s to the 1980s (p. 21). It is difficult to pinpoint the exact beginning and end of the three waves of feminism because they overlap each other. Some of the main points during the very beginnings of the second-wave feminist period that affected the transition of these female journalist characters in film from before and after include the Equal Pay Act of 1963, the Civil Rights Act of 1964 , the ability to access contraception, and the inclusion of women with different ethnic backgrounds in the women's movement ("Second wave," 2014). These accomplishments led the 
women's rights movement into the late 1960 s, coinciding with the civil rights movement (“Second wave," 2014).

President John F. Kennedy appointed Ester Peterson to the head of the Women's Bureau in the Department of Labor in 1961. Her role was to create a Presidential Commission on the Status of Women. The commission operated from 1961 to 1963 and produced a report, “American Women," which paved the way for the Equal Pay Act of 1963. The next year, the Civil Rights Act of 1964 was passed with an amendment that said both men and women were protected against employment discrimination.

Laughlin and Castledine (2012) point out that second-wave feminists were the first group from any of the feminist movements to "make a demand for sexual equality central to their agenda" (p. 247). This rings true with the journalists portrayed in the films that will be analyzed for this study. The female journalists that are portrayed in American films during and after the second-wave feminist movement feel they deserve the same opportunities as a man does in and out of the workplace. They clearly express this by complaining to their bosses, co-workers, and lovers when they are not given the same opportunities as their male co-workers. In the American films before the second-wave feminist movement, the female journalists are portrayed as strong women, but they accept that they are not going to receive the same tasks to complete in the workplace as their male counterparts. This personality trait of acceptance contributes to the sob sister persona that is exhibited in the female journalist characters portrayed before the secondwave feminism movement.

In 1907, the term "sob sister" was coined during Harry Kendall Thaw's trial for murdering Stanford White (Lutes, 2003). The term was coined to describe "a female journalist who specialized in sentimental or human-interest stories, or more generally, a woman writer 
'who could wring tears,"' (p. 504). These female journalists were derogatorily given this term to describe their abilities to play on the emotions of the readers (Lutes, 2003). This term was transferred into the portrayals of female journalists in film (Saltzman, 2002). In the early $20^{\text {th }}$ century, female journalists were shown to be a male journalist's equal but often showing a softer side (pp. 10-11). According to Saltzman, by the end of these early $20^{\text {th }}$ century films, "most sob sisters, no matter how tough or independent, would give up anything and everything for marriage, children, and a life at home" (p. 11).

During the women's movement in the real world of journalism, the main female journalist who pioneered the way for other women was Barbara Walters (Olson, 2012, p. 8). When she started working on $A B C$ Evening News in 1976 as the first female network news coanchor, Walters received a $\$ 5$ million contract for five years, where she would be paid $\$ 1$ million annually (Lipton, 2001, p. 80). She broke the barrier for other female journalists, including Connie Chung, Diane Sawyer, and Katie Couric (Olson, 2012). Other female journalists who paved the way for women during second-wave feminism were Helen Thomas, a White House press journalist; Judy Woodruff, a television journalist for CNN, NBC News, and PBS; and Charlayne Hunter-Gault, a media journalist for National Public Radio and the Public Broadcasting Service. Some of the characteristics of female journalists portrayed in American film transformed as a result of people like Barbara Walters, Helen Thomas, Judy Woodruff, and Charlayne Hunter-Gault, who helped pave the way for female journalists during the women's movement.

The eight films that are to be analyzed (Platinum Blonde; Mr. Deeds Goes to Town; His Girl Friday; Woman of the Year; Superman; The China Syndrome; Absence of Malice; and Broadcast News), display traits that develop or change before and after the second-wave feminist 
period. Events during the women's movement, such as Barbara Walters' breakthrough as the first female evening news co-anchor, help to support the transition of the characteristics that the female journalists portray in American film before and after the second wave.

\section{Female Journalists in the Real World}

According to McPherson (2006), during the late 1960s and early 1970s in the real world, it was difficult for females to be accepted as serious journalists. Many female television journalists started as "weather girls" because that is the only position management would give them. In the sports field, female sports reporters also received criticism from their fellow male reporters in the press box. Female journalists finally found some equality with men when reporting from Vietnam, with 267 women journalists accredited by the United States military. However, even in Vietnam, the women were expected to cover the "softer" stories for the news, partially because military officers were sometimes hesitant to take female reporters on an operation than they were male reporters (pp. 12-13).

According to Becker, Lauf, and Lowrey (1999), in 1971, female journalists made up just 20 percent of the workforce in journalism. This number increased to 34 percent in 1982-83, remained stagnant at 34 percent in 1992, and increased to 37 percent in 1998. Only four percent of daily newsrooms consisted of minorities in 1978. That number increased to just eight percent in 1990 (p. 633). From these statistics, women are not represented well in daily newsrooms across the United States.

According to the 2014 census of the American Society of News Editors, 63 percent of the news organizations surveyed have at least one woman among their top three editors. According to Hardin and Shain (2005), the average career span for female journalists in the sports 
department is only 10 years, and most never gain a management position (p. 23). Since the 1920s, female reporters have been seen as the most auspicious personification of an assertive female in a profession. This is a quality that is exhibited in the characteristics of the women journalists portrayed in the films that will be observed, as well as many other journalism films. Before the second wave, with the lack of a feminist movement, some women of the 1930s were dissatisfied with their subordinate status. This included Mildred Augustine Wirt Benson, a journalist and the original author of the Nancy Drew series. According to Rehak (2005), when Benson was a reporter, she refused to write for the women's pages, referring to them as "jams and jellies" (pp. xvi-xvii). Her father owned a publishing company, and when he died, she became a female CEO, which is rare even for today. She stood up against the men who did not treat her well in the company and worried about how to take care of her family when there were few resources for working mothers at the time (p. xvi). Benson was seen as a pioneer at a time when there was not much happening for women's rights (p. xvii).

\section{Female Journalists in Film}

According to Valencia et. al. (2008), one out of five journalists in film is a woman (p. 223). Out of that 20 percent, three out of every four women, 70.5 percent, are between the ages of 20 and 35 (p. 224). This is a large percentage compared to male journalists represented in the same age group in film, which is only 31 percent. Valencia et. al. state that the age statistics for women could be because "... either they die earlier, or they receive favorable treatment and retire sooner" in film (p. 223). A good appearance is also a factor for gender portrayals of journalists in film: "a value for the men, a requirement for the women" (p. 224). 
Valencia et al. hypothesize that there seems to be a "sexual division" between hard news and soft news in film related to gender, giving women the tendency to cover soft news and care about it more, while the men cover the hard news. The authors discovered their findings from a research report entitled Gender Representation in Radio and Television News Programs, which stated that this hypothesis is false. According to the report, these "significant differences are established" only in the sports sector of journalism (p. 226).

Another subject that Valencia et al. covers is the personal lives and love lives of male and female journalists in film. In the case of the male journalists, we do not know the marital status 37 percent of the time. For female journalists, we do not know the marital status six percent of the time. Valencia and the other authors present a couple of arguments on this subject. One argument is that since there are fewer female journalists in film, and they are usually the leading characters, the viewer will want to know about their personal lives. Their other argument is that female journalists might need a storyline with a sentimental life to keep viewers interested, as opposed to male journalists, whose professional career is enough (p. 227).

Interestingly, Valencia et al. found that there is a similar proportion of male and female journalists in film that are single. According to their findings, 59 percent of females are single and 52 percent of males are single. It was also discovered that the same proportion of male and female journalists in film are separated, which equates to three percent. When it comes to divorce, though, three times as many female journalists are divorced compared to male journalists: six percent of women as opposed to three percent of men.

At the same time, Valencia et al. said there are twice as many married male journalists in film, compared to female journalists (pp. 227-228). Eighteen percent of male journalists are 
married, while nine percent of female journalists are married (Valencia, et. al., 2008). That adds another statistic that is doubled when it comes to gender portrayals of journalists in film. With children, male journalists have them but do not have time for them because of their profession, so the wives have to take care of them. (p. 228). Female journalists do not have children because they don't have the stay-at-home husbands who will take care of the children in film (p. 228). According to Sistiaga (2004), though, with a new field of female journalists, they are now reporting on wars a lot more, like the Iraq War (as cited in Valencia et al., 2008, p. 236). Blanco (2005) said that women also occupy many director positions in the journalism world. Out of all women directors in journalism, 78 percent are directors of magazines (as cited in Valencia et al., 2008, p. 226).

There are times when journalists are inaccurately portrayed as glamorized by Hollywood when it comes to their professional and personal lives. For example, in Absence of Malice (1981), Megan Carter lives in a large apartment in Miami. In reality, a female print journalist in 1981 most likely could not afford such a nice apartment, especially in a large city like Miami. Not even a male print journalist could probably afford such a nice apartment during that time, especially in Miami. The fact that Hollywood glamorizes these roles gives the audience of these films a misleading perception about the journalism profession and the personal lives that the journalists lead. 


\section{Research Questions}

The findings of this thesis will attempt to answer the following research questions:

RQ1: What personality characteristics have changed, stayed the same, or evolved in the portrayals of female journalists in American film from first-wave feminism to the end of secondwave feminism?

RQ2: What real-world factors during second-wave feminism were correlated with the characteristics in the portrayals of female journalists in American film?

\section{Methodology}

Mayring (2000) defined a qualitative content analysis as "an approach of empirical, methodological controlled analysis of texts within their context of communication, following content analytical rules and step-by-step models, without rash quantification" (para. 5). Mayring also stated this includes "recorded communication," which would include the films and characters analyzed in the research process (para. 4). The thesis will be a qualitative content analysis using Sartre's interpretation of phenomenology to examine whether the characteristics of female journalists portrayed in American film have changed or stayed the same before and after second-wave feminism. Specifically, the characteristics of the main female journalists in Platinum Blonde; Mr. Deeds Goes to Town; His Girl Friday; Woman of the Year; Superman; The China Syndrome; Absence of Malice; and Broadcast News will be observed. Platinum Blonde; His Girl Friday; and Woman of the Year are from the first-wave feminist period, while The China Syndrome, Absence of Malice, and Broadcast News are from the second-wave feminist period. Sartre's version of phenomenology fits well with how female journalists are portrayed in 
film. For example, Grosz (1989) wrote that according to Sartre, "the human being has at least one immutable, fixed characteristic: its essence is determined by its existence" (p. 7). Sartre's interpretation of Husserl's phenomenology will help to explain whether the characteristics of female journalists portrayed in American film have changed or stayed the same before and after the second-wave feminism period. Sartre's interpretation also helps to expand the structure of phenomenology as a whole.

The Stanford Encyclopedia of Philosophy (2013) defines phenomenology as the following:

Phenomenology is the study of structures of consciousness as experienced from the firstperson point of view. The central structure of an experience is its intentionality, its being directed toward something, as it is an experience of or about some object. An experience is directed toward an object by virtue of its content or meaning (which represents the object) together with appropriate enabling conditions (Phenomenology introduction, para. $1)$.

Phenomenology is studied from the first-person point of view, which makes Sartre's interpretation vital to this study. It helps to individualize and humanize each of the female journalists who are portrayed in the American films to be analyzed in this thesis. The phenomenological first-person point of view also helps when analyzing their "immutable, fixed characteristics" (Grosz, 1989, p. 7). According to Grosz (1989), Sartre was attempting to "humanize and individualize" Husserlian phenomenology in Being and Nothingness (p. 6).

Husserl's own definition of phenomenology (as cited in the Stanford Encyclopedia of Philosophy, 2013) is "... the science of the essence of consciousness, centered on the defining 
trait of intentionality, approached explicitly in the first person" (The History and Varieties of Phenomenology section, para. 4). With the two above definitions, one would seem to understand that the female journalists in the films analyzed in this study all have strong personalities that they exhibit through a first-person point of view. They have their own intentions and virtues that they try to establish or pursue through their own set of experiences in their own first-person points of view.

Husserl's version of phenomenology was more "academic" and "rigorous" when it came to his analysis of consciousness (Churchill \& Reynolds, 2013). On the other hand, Sartre expanded Husserl's view with a more existential and idealistic approach (pp. 12-13). Gines (2011) said that existentialism is "frequently overused" and "often over-determined" (p. 47). As a result, a direct definition of existentialism from Sartre seems necessary. According to Sartre (1957), existentialism is "a doctrine, which makes human life possible and, in addition, declares that every truth and every action implies a human setting and a human subjectivity" (p. 10). This fits the female journalists portrayed in the films analyzed as they think about their love lives, professional lives, and the dilemmas they face in everyday life. Sartre (1957) also says, "Man exists, turns up, appears on the scene, and, only afterwards defines himself" (p. 15). This applies to the female journalists portrayed in film because they seem to only completely find and understand themselves at the end of the film after having gone through the dramatic events that make up their personal and professional lives.

According to Wang (2006), Sartre did not believe that individuals are complete and that they sought after two things simultaneously “... to possess a secure and stable identity, and to preserve the freedom and distance that come with self-consciousness" (p. 1). This applies to the female journalists portrayed in the films that are analyzed because they are trying to figure out 
who they are as they live in what they see as a man's world. The female journalists portrayed in film before the second-wave feminist movement seem as if they will never be able to obtain freedom from men and shatter the glass ceiling. The female journalists portrayed after the movement have to prove to themselves and others that their identities are stable and secure to obtain that freedom in their own self-consciousness.

Grosz (1989) defined humanism as "the belief that all values, meanings, history and culture are the products of human consciousness and individual activity" (p. 6). She also stated, "It conflates the subject and consciousness, granting primary value to consciousness in making choices and judging, creating and transforming social relations" (pp. 6-7). She used this definition when discussing Sartre's interpretation of Husserl's phenomenology. Grosz also stated that existentialism is Sartre's own translation of phenomenology. According to her, Sartre's version "espouses the primacy of the subject's experiences in ontological, political, social, and interpersonal relations" (p. 7).

Sartre's interpretation of Husserl's phenomenology fits well with how female journalists are portrayed in film. For example, Grosz wrote that according to Sartre, "the human being has at least one immutable, fixed characteristic: its essence is determined by its existence" (p. 7). That said, female journalists portrayed in film had similar stereotypes before and after the second-wave feminist period. Sartre's interpretation of phenomenology helps to explain why female journalists have very similar stereotypes in every American film before and after the period.

Foucault's point about discourse and identity adds to the issues about essence and existence. Bannister (2010) interpreted Foucault's conviction, saying "identity is not within us, it is what we continuously create in interaction with others" (pp. 172-173). Grosz (1989) stated 
that Foucault had said "... the body, as much as other cultural objects, is the product and effect of various systems of training, discipline and construction" (p. x). Foucault's ideas support the firstperson point of view of phenomenology, as well as how film and the characters represented in those films, are created and viewed by the real world.

\section{Rationale for Films Selected}

Pat Hanson, the executive editor of the American Film Institute's catalog and head of its library stated "I feel a classic is something that has a patina of age, and is also something you can look at and admire at any age. It transcends a time frame" (Gilbert, 2009). Diane Borden, the director of the University of the Pacific's film studies program also gave her own definition of what makes a film a classic:

In my mind, a classic has to do with films that are somewhat older, have been established, that have been critically acclaimed, that are a foundation for film study, that made a great impact and remain fresh, alive. A classic film is a work of art that consistently, over time has merit and importance (Gilbert, 2009).

These eight films were chosen because they exhibit the above characteristics listed, and they are all considered film classics about journalism. As stated before, these eight films were also chosen to provide a sizable sample of the films that were considered "classics" during the time periods that were examined. Personality characteristics that will be analyzed will be the sob sister persona and their relationship statuses. This research will support that the sob sister persona does not continue past first-wave feminism into second-wave feminism, while the characters' relationship statuses evolve during the second-wave feminist period. A coding sheet will be used to assess the listed characteristics of the female journalists portrayed in the eight 
films. Two coders will analyze the characteristics of the female journalists with Cohen's kappa coefficient to test the inter-rater agreement, which will ensure accuracy and reliability.

\section{Real-World Factors to Be Considered}

Factors that will be considered as correlatives to the characters' changing personalities will include Title IX of the Education Amendments Act of 1972, the Equal Pay Act of 1963, Title VII of the Civil Rights Act of 1964, Griswold v. Connecticut (1965), Eisenstadt v. Baird (1972), Reed v. Reed (1971), Roe v. Wade (1973), and the creation of the National Organization for Women (1966). The following subheadings are short definitions of each of the eight realworld facts that are to be considered.

\section{The Equal Pay Act of 1963}

The Equal Pay Act of 1963 "prohibits discrimination on account of sex in the payment of wages by employers engaged in commerce or in the production of goods for commerce" (United States Equal Employment Opportunity Commission, 1963).

\section{Title VII of the Civil Rights Act of 1964}

The purpose of Title VII of the Civil Rights Act of 1964 is:

“... to enforce the constitutional right to vote, to confer jurisdiction upon the district courts of the United States to provide injunctive relief against discrimination in public accommodations, to authorize the Attorney General to institute suits to protect constitutional rights in public facilities and public education, to extend the Commission on Civil Rights, to prevent discrimination in federally assisted programs, to establish a 
Commission on Equal Employment Opportunity, and for other purposes" (United States Equal Employment Opportunity Commission, 1964).

\section{Title IX of the Education Amendments Act of 1972}

Title IX prohibits discrimination on the basis of sex in education programs or activities operated by recipients of Federal financial assistance.

\section{Griswold v. Connecticut (1965)}

The Griswold v. Connecticut (1965) decision stated that married couples had a right to use contraceptives to prevent procreation. The Supreme Court decided that the Connecticut statute that had previously forbid it violated marital privacy.

\section{Eisenstadt v. Baird (1972)}

The Eisenstadt v. Baird (1972) decision expanded on the Griswold v. Connecticut (1965) decision, allowing unmarried people to acquire contraception the same way married couples were allowed, implying that unmarried couples were allowed to engage in sexual intercourse that would result in not procreating.

\section{Reed v. Reed (1971)}

The Reed v. Reed (1971) decision said that estate administrators could not be named in a way that showed gender discrimination.

\section{Roe v. Wade (1973)}

The Roe v. Wade (1973) decision gave women the right to choose whether to have an abortion during pregnancy. 


\section{The Creation of the National Organization for Women (1966)}

The National Organization for Women, the largest organization of women activists in the United States, was founded in 1966 during the second-wave feminist movement. The organization's purpose is "to take action" to bring equality for all women ("Who We Are," n.d., para. 1).

\section{Results}

\section{Inter-coder Reliability}

Inter-coder reliability was used to ensure validity in the coding scheme for this study. One Caucasian male and one Caucasian female were selected to code the eight films that were used for this study. Both coders were trained beforehand to ensure an understanding of the study's coding process. To make sure the two coders were reliable, two of the eight films, one film from before the second-wave feminist movement and one during the period, were used to verify reliability between the two coders. As a result, the two films could not be used in the overall sample. Cohen's Kappa coefficient was used to measure the concordance between the two coders. The system used to determine this was Statistical Package for the Social Sciences (SPSS), which accurately computed the coders' results and calculated the inter-coder reliability. As shown below, there was a 100 percent agreement between the two coders. 
Table 1: Inter-coder Reliability of the Variable Used in the Study

\begin{tabular}{|l|r|r|r|r|}
\hline & \multicolumn{1}{|c|}{ Symmetric Measures } \\
\hline & Value & $\begin{array}{c}\text { Asymp. Std. } \\
\text { Error }^{\mathrm{a}}\end{array}$ & Approx. T $^{\mathrm{b}}$ & Approx. Sig. \\
\hline $\begin{array}{l}\text { Measure of Agreement Kappa } \\
\text { N of Valid Cases }\end{array}$ & 1.000 & .000 & 3.464 & .001 \\
\hline
\end{tabular}

RQ1: What personality characteristics have changed, stayed the same, or evolved in the portrayals of female journalists in American film from first-wave feminism to the end of second-wave feminism?

In order to clearly view the differences of the characteristics that have changed, stayed the same, or evolved, each movie's results will be displayed separately. Afterward, the results of the three movies before the second-wave feminist movement and the three movies during/after the decline of the second wave will be compared and contrasted. Movie 1: Platinum Blonde (1931) and Movie 5: Superman (1978) will not be included in the analysis of RQ1 due to their use in the Cohen's Kappa coefficient inter-coder reliability test.

Movie 2: Mr. Deeds Goes to Town (1936)

According to the two coders, when it came to the female journalist's relationship status, she is single at the beginning of the movie, but at the end, she is dating. She does not have any children. The film takes place before the second-wave feminist movement, but the character did not portray the sob sister persona. She is a print reporter working for an entertainment media outlet. She does not appear to advance her career during the film. 


\section{Movie 3: His Girl Friday (1940)}

According to the two coders, the female journalist is engaged at the beginning of the film and is also engaged at the end of the film. She does not have children. The film takes place before the second-wave feminist movement, and the character does portray the sob sister persona. She is a print reporter working for a news media outlet. She does not appear to advance her career during the film.

\section{Movie 4: Woman of the Year (1945)}

According to the two coders, the female journalist is single at the beginning of the film and married at the end of the film. She does have an adopted son who is a Greek refugee. The film takes place before the second-wave feminist movement, but the character does not portray the sob sister persona. She is a print reporter for a political media outlet. She does appear to advance her career during the film.

\section{Movie 6: The China Syndrome (1979)}

According to the two coders, the female journalist is single at the beginning of the film, as well as single at the end of the film. She does not have children. The film takes place during/after the decline of the second-wave feminist movement, and the character does not portray the sob sister persona. She is a television reporter for a news media outlet. She does not appear to advance her career during the film.

\section{Movie 7: Absence of Malice (1981)}

According to the two coders, the female journalist is single at the beginning of the film, as well as single at the end of the film. She does not have children. The film takes place 
during/after the decline of the second-wave feminist movement, and the character does not portray the sob sister persona. She is a print reporter for a news media outlet. She does not appear to advance her career during the film.

\section{Movie 8: Broadcast News (1987)}

According to the two coders, the female journalist is single at the beginning of the film and dating at the end of the film. She does not have children. The film takes place during/after the decline of the second-wave feminist movement, and the character does not portray the sob sister persona. She is a television producer at a news media outlet. She does appear to advance her career during the film.

\section{Analysis of RQ1 Results}

When it comes to the results of the dating lives of the three female journalists analyzed before the second-wave feminist movement, there is a pattern that all of the female journalists are in a relationship, whether they are dating, engaged, or married. Two of the three female journalists during/after the decline of the second wave are single, with only one dating at the end of the film. Though, it can be seen as difficult to fully classify the dating aspect of the female journalists. For example, in Absence of Malice (1981), Megan Carter's character has a brief affair with Michael Gallagher, a man accused of being involved in the disappearance and possible murder of a union official. According to the coding results, the two coders did not count the brief affair as a relationship.

Out of the six films, the two coders found that the sob sister persona was only portrayed in His Girl Friday (1940). This could be due to the fact that Hildy Johnson's character interviews the accused man in the film, sympathizes with him, and tries to change the public's 
mind about his potential hanging with the articles that she writes. The print story could be seen as a sentimental story, in which Hildy Johnson is trying to "wring tears" from the public. As expected, the sob sister persona was not portrayed in any of the films analyzed after the second wave.

Tess Harding's character in Woman of the Year (1942) was the only female journalist to have a child. Interestingly, the child was adopted, which seems advanced for the time period of the film. This could reflect on how the character of Tess Harding was so advanced in the career world as a journalist and as a woman. All three female journalists before the movement were print journalists, while two out of three portrayed during/after the decline were television journalists. This is could be because of the popularity of print journalism versus television journalism. Out of the six films, Tess Harding's character in Woman of the Year (1942) and Jane Craig's character in Broadcast News (1987) were the only female journalists who appeared to have advanced their careers during the film.

\section{Discussion}

\section{RQ2: What real-world factors during second-wave feminism were correlated with the characteristics in the portrayals of female journalists in American film?}

Two themes that run through most of the observed real-world factors are privacy and autonomy. It is clear that there were two of the main issues debated during the second-wave feminist movement. Whether it is the right to use contraceptives, to be named as an administrator of an estate, or to have an abortion, privacy and autonomy are two of the main factors for which women during the movement had to fight to be sure that they were treated as men were treated. Today, it may seem absurd to think that a woman would not be able to make 
these decisions for herself. Though, issues like contraception and abortion are still debated today. It is also interesting that women had to have these choices made for them by other people, because judges, primarily men at the time, still had the right to make the decisions for them. Many of these cases, including Griswold v. Connecticut (1965), Eisenstadt v. Baird (1972), Reed v. Reed (1971), and Roe v. Wade (1973) are also considered landmark cases because of the impact they had on the American society.

The following eight real-world factors during the second-wave feminist movement were examined to determine to what degree they ran parallel with changes in the personality characteristics of the eight female journalist characters that were examined. These eight factors were chosen because they were vital for women during the movement with breakthroughs in such areas as their careers, families, personal lives, and personal choices. Before each factor is discussed, the previous definitions of the eight factors are provided again to allow the reader to recall what each factor represents. Movie 1: Platinum Blonde (1931) and Movie 5: Superman (1978) will not be included in the analysis of RQ2 due to their use in the Cohen's Kappa coefficient inter-coder reliability test.

\section{The Equal Pay Act of 1963}

The Equal Pay Act of 1963 "prohibits discrimination on account of sex in the payment of wages by employers engaged in commerce or in the production of goods for commerce" (United States Equal Employment Opportunity Commission, 1963). Unfortunately, females in the workplace today are still paid less than their male counterparts. According to Alter (2014), recent research provided by Wells Fargo said millennial men with a college education made $\$ 20,000$ more per year than women with an equal education, giving men a median annual 
income of $\$ 83,000$ and women only $\$ 63,000$ (p. 51). In addition, according to the Pay Equity Overview (2014), in 2012, female workers who worked full-time, year-round had a median annual income that was 76.5 percent of male worker with a similar job. That gave women an income of $\$ 37,791$ versus $\$ 49,398$ for men (p. 3). With the financial evidence stated, it is clear that the work of feminists to acquire the right of equal pay is an ongoing battle, even if a law that was passed says that they are to be paid the same as men. This real-world factor may not have changed the characteristics of the female journalists portrayed in the films, but to the degree that the film mirrored real life, it is possible that it influenced the type of journalism position the character had, how she lived, and whether or not she advanced in her career.

\section{Title VII of the Civil Rights Act of 1964}

The purpose of Title VII of the Civil Rights Act of 1964 is:

... to enforce the constitutional right to vote, to confer jurisdiction upon the district courts of the United States to provide injunctive relief against discrimination in public accommodations, to authorize the Attorney General to institute suits to protect constitutional rights in public facilities and public education, to extend the Commission on Civil Rights, to prevent discrimination in federally assisted programs, to establish a Commission on Equal Employment Opportunity, and for other purposes (United States Equal Employment Opportunity Commission, 1964).

Title VII can be seen as an extension or aid to the Equal Pay Act of 1963. It is important to the second-wave feminist movement because it was another step to women being seen as the equals of men in the workplace. It was especially vital to African American women, since the Civil Rights Act of 1964 aided in the start of desegregation in America. This real-world factor is 
important to the female journalist portrayals in the films because as the four films before the movement are compared with the four after, there is evidence that the female journalists are treated differently. For example, the term "sob sister" is thrown around throughout the films before the movement, sometimes in front of the female journalists themselves. This could be seen as hurtful and disrespectful to the female journalists, but they do not seem phased by it. It could be either because that is just how the world was at the time and they were used to being spoken to in that manner, or perhaps it is because they are trying their best to be professional and push through.

As the films progress to after/during the decline of the movement, the women are still sometimes talked about as objects, but as the films continue through the movement, there is more evidence of equality. It is as if the women have to prove themselves to show that they are the equals of men. For example, at the beginning of The China Syndrome, Kimberly Wells is getting ready to go on camera, and the producers are talking about her looks as a woman, as if she is an object and not a person. They comment how her new red hair looks good, and how they are thinking of getting her hair cut (Rose, 1980, p. 2-3). They then say that she won't care because "she'll do what we tell her" (p. 3). She is also given the fluff pieces to cover instead of the hard news stories the male television journalists are able to cover. By the end of the movie, she may not have advanced in her career, but she has shown that she is an equal of her male counterparts when she breaks the story of the danger at the nuclear plant.

As the time period of the movement moves to Broadcast News, Jane Craig's character is treated as more of an equal of men. Her career as a Washington, D.C. television news producer is even admired by the male main anchor from the New York bureau. However, she does break down crying throughout various points in the film. According to Lutes' definition, though, this 
does not constitute her as a sob sister. She does come into a confrontation with an older network executive over a disagreement. The network executive finally mocks her and says, "You're just absolutely right, and I'm absolutely wrong. It must be nice to always believe you know better...To always think you're the smartest person in the room." Jane responds, "No, it's awful," (Brooks, 1987).

\section{Title IX of the Education Amendments Act of 1972}

According to Ali Russlyn (2011), a former Assistant Secretary of the United States Department of Education, Title IX “... prohibits discrimination on the basis of sex in education programs or activities operated by recipients of Federal financial assistance" (p. 1). Although the education history of the portrayed female journalists is not discussed at length in the films, Title VII of the Civil Rights Act of 1964 would have possibly been a real-world factor assisting the female journalists portrayed after the second-wave feminist movement when it came to their college careers and higher education. It could have influenced the characteristic of furthering the female journalists' careers. With a college education, the characters would have had a better chance to advance more rapidly, especially in those times when a college degree was not as common as it is today.

\section{Griswold v. Connecticut (1965)}

The Griswold v. Connecticut (1965) decision stated that married couples had a right to use contraceptives to prevent procreation. The Supreme Court decided that the Connecticut statute that had previously forbid it violated marital privacy. The only married couple in all of the films examined in this study would have been Tess Harding and her husband in Woman of the Year. That film came out in 1945, and they adopted a son, so they could have possibly been 
using birth control illegally, or maybe one or both of them could not have children. This factor would only have helped Tess Harding and her husband, for none of the other characters were currently married during the other films. This court case also incorporates the theme of privacy that women were trying to achieve.

\section{Eisenstadt v. Baird (1972)}

The Eisenstadt v. Baird (1972) decision expanded on the Griswold v. Connecticut (1965) decision, allowing unmarried people to acquire contraception the same way married couples were allowed, implying that unmarried couples were allowed to engage in sexual intercourse that would result in not procreating. This extension of the previous court case was vital to the female journalist characters portrayed after the second-wave feminist movement. Although Kimberly Wells does not have a relationship during the course of The China Syndrome, both Megan Carter in Absence of Malice and Jane Craig in Broadcast News do. This factor was important for the relationship characteristics of these three characters. It gave them more independence and more options so that if they did not want to date or get married and have children, they could choose to do so. This court case also exhibits the theme of privacy, extending the scope of privacy women received from Griswold v. Connecticut (1965).

\section{Reed v. Reed (1971)}

The Reed v. Reed (1971) decision said that estate administrators could not be named in a way that showed gender discrimination. This was the first time that the United States Supreme Court ruled that the Equal Protection Clause of the Fourteenth Amendment banned gender discrimination (Reed v. Reed, 1971). Although this factor may not seem like it could influence the characteristics examined, it could be seen as an influence on the advancement of the female 
journalists' careers along the lines of gender discrimination. This verdict could have been a factor in aiding Title VII of the Civil Rights Act of 1964 with gender equality in the workplace. As evidenced in the female journalist roles examined, most female journalists did not have anything higher than a reporting position until Jane Craig in Broadcast News. She was a producer in a large Washington, D.C. television news bureau, and she is also seen directing at some point, as well. At the end of the film, it flashes forward seven years later, and she has taken an offer as a managing editor at the New York bureau. Broadcast News seems to display an accurate depiction of women moving up the ladder toward the end of the movement.

\section{Roe v. Wade (1973)}

The Roe v. Wade (1973) decision gave women the right to choose whether to have an abortion during pregnancy. This factor is important to the female journalists' characteristics examined in the films because it blends with the Griswold v. Connecticut (1965) and Eisenstadt v. Baird decisions of privacy and birth control. The Roe v. Wade (1973) verdict was another landmark court case that dealt with the issue of privacy and women's rights. This court case would allow the female journalist characters portrayed after the movement the right to decide whether they would want to start a family as a married woman, a woman in a relationship, or even a single woman. Though, it does not seem to have affected the women in the chosen films. This court case includes both the privacy and autonomy themes that were discussed earlier.

\section{The Creation of the National Organization for Women (1966)}

The National Organization for Women, the largest organization of women activists in the United States, was founded in 1966 during the second-wave feminist movement. The organization's purpose is "to take action" to bring equality for all women ("Who We Are," n.d., 
para. 1). This factor is important to the characteristics of the female journalists portrayed in the examined films because this organization had the ability to give the female journalist portrayed after the movement the feeling of empowerment and independence. These feelings could extend to how they felt in the workplace, how they felt about advancing their careers, and how they felt about having successful personal lives and relationships. Those feelings resonate today, as the National Organization for Women is still fighting for women's rights.

\section{Thoughts about Sartre and Feminism}

According to the Stanford Encyclopedia of Philosophy (2013), Sartre was a fan of feminism, even though some of his early work was sexist in nature (“Jean-Paul Sartre," sec. 7, para. 8). Murphy (1999) also mentions that many feminist philosophers have used much of Sartre's Being and Nothingness as a reference for their own work (p. 8). In fact, the Stanford Encyclopedia of Philosophy states that Sartre was intrigued by the idea of feminism so much, that he encouraged his lover, Simon de Beauvoir, to publish her book about feminism titled The Second Sex (“Jean-Paul Sartre,” sec. 7, para. 8).

Sartre died in 1980, so he was alive for most of the change that happened during the second-wave feminist movement. It seems that Sartre had feminism in mind when he wrote about phenomenology. As mentioned before, according to Grosz (1989), Sartre was attempting to "humanize and individualize" Husserlian phenomenology in his book Being and Nothingness (p. 6). It is potentially evident that Sartre had feminism in mind when interpreting Husserl's thoughts about solely experiencing consciousness and intentionality in the first person. Sartre explained that a person's nature is determined by their existence, and it seems like he thought 
women should be able to determine their own paths in life without having their decisions made for them.

\section{Expected Results and Implications of the Study}

The purpose of this study was to give individuals interested in journalism, film, or feminism a lens through which to view these films and others like it. The results of this study will hopefully help future researchers understand more about the first and second waves of the feminist movement, as well as more about the third wave. It was expected that there would be consistencies in the relationship and maternal statuses of many of the characters that would be analyzed in this thesis. All of the characters portrayed before the second-wave feminist period were involved in some type of a relationship, while only one female journalist portrayed during the decline/after the movement was involved in a relationship, which did not happen until the very end of the film. Most of the characters portrayed after the movement wanted to keep their independence because of the type of work they were in, instead of compromising it for a relationship, marriage, or children. As expected, there was only one female journalist, portrayed before the movement, who had a child, and that child was adopted.

A disadvantage to this study is that all of the female leading journalists portrayed in the observed films are Caucasian. Coincidentally, there are few African-American female leading journalists in American film. The results of this paper were not biased toward Caucasians since most female leading journalists portrayed in American film are already Caucasian. There are no representations of homosexuality in any of the main female characters, either, with all eight of them being heterosexual. These results could obviously change if the research were to be 
conducted using countries besides the United States. Future researchers who build on the findings presented in this thesis could study films from other countries to get a different perspective of how female journalists of different ethnicities are portrayed outside of the United States.

Another disadvantage to this study is the fact that all of the directors of the films and almost all of the writers who were examined were male. This could potentially limit the ways that the female journalists, or females in general, are portrayed in these films. Future researchers who expand on these findings could seek out American films about journalists and journalism that are directed by both males and females to get a better balance in their results. This could prove difficult, though, for there are not many female directors who direct American films, especially journalism-related American films. Five out of eight of the films were distributed by Columbia Pictures, which could also be a further disadvantage to the study because the studio could potentially be biased in their portrayals of female journalists. 


\section{References}

Alter, C. (2014). Millennial women are still getting paid less than men. Time.Com, 51. Retrieved from http://search.ebscohost.com.www.libproxy.wvu.edu/login.aspx?direct=true $\& d b=a 9$ h\&AN=96583986\&site=ehost-live

Alterman, E. (2012). The girl who loved journalists. Columbia Journalism Review, 50(5), 12-16.

Bannister, M. (2010). "I'm set free...”: The velvet underground, 1960s counterculture, and michel foucault. Popular Music \& Society, 33(2), 163-178. doi:10.1080/03007760903142889

Becker, L. B., Lauf, E., \& Lowrey, W. (1999). Differential employment rates in the journalism and mass communication labor force based on gender, race, and ethnicity: Exploring the impact of affirmative action. Journalism \& Mass Communication Quarterly, 76(4), 631645. doi:10.1177/107769909907600402

Bergoffen, D. (2012). The society for phenomenology and existential philosophy, feminism, and the epoché. Journal of Speculative Philosophy, 26(2), 278-290. Retrieved from http://search.ebscohost.com.www.libproxy.wvu.edu/login.aspx ?direct=true $\& d b=a 9$ h\&AN=82115267\&site=ehost-live

Blanco Castilla, Elena (2005). "Mujer y poder en los medios: Dificultades para una incorporación plena". In: Informe Anual de la Profesión Periodistica 2005. Asociación de la Prensa de Madrid.

Brooks, J. L. (Producer/Director). (1987). Broadcast news [Motion picture]. United States: $20^{\text {th }}$ Century Fox Film Corporation. 
Churchill, S., \& Reynolds, J. (Eds.). (2013). Jean-Paul Sartre: Key Concepts. London, GBR: Acumen. Retrieved from http://www.ebrary.com

Dasilva, J. Á. P. (2008). ... So what? she's A newspaperman and she's pretty. women journalists in the cinema. Zer: Revista De Estudios De Comunicacion, 13(25), 221-242.

Eisenstadt v. Baird, 405 U.S. 438 (1972). Retrieved from http://caselaw.lp.findlaw.com/cgi bin/getcase.pl?court=us\&vol=405\&invol=438

Feminism. (n.d.). In Merriam-Webster.com. Retrieved July 15, 2014, from http://www.merriamwebster.com/dictionary/feminism

Flynn, Thomas. (2013). Jean-Paul Sartre. In The Stanford Encyclopedia of Philosophy Retrieved from http://plato.stanford.edu/archives/fall2013/entries/sartre/

Gilbert, L. (2009). Local film buffs debate what makes a classic. ().Record, The (Stockton, CA). Retrieved from http://search.ebscohost.com.www.libproxy.wvu.edu/login.aspx?direct=true \&db=nfh \&AN=2W62W62527146776\&site=ehost-live

Gines, K. T. (2011). "The man who lived underground": Jean-paul sartre and the philosophical legacy of richard wright. Sartre Studies International, 17(2), 42-59. doi:10.3167/ssi.2011.170204

Good, H. (1998). Girl reporter: Gender, journalism, and the movies. Lanham, MD: Scarecrow Press

Gordon, L. (2013). Socialist feminism: The legacy of the "Second wave". New Labor Forum (Sage Publications Inc.), 22(3), 20-28. doi:10.1177/1095796013499736 
Griswold v. Connecticut, 381 U.S. 479 (1965). Retrieved from http://caselaw.lp.findlaw.com/scripts/getcase.pl?court=US\&vol=381\&invol=479

Grosz, E. A. (1989). Sexual subversions: Three French feminists. Sydney; London: Allen \& Unwin.

Hardin, M., \& Shain, S. (2005). Female sports journalists: Are we there yet? 'no'. Newspaper Research Journal, 26(4), 22-35. Retrieved from http://search.ebscohost.com.www.libproxy.wvu.edu/login.aspx?direct=true \&db=a9 h\&AN=19762776\&site=ehost-live

Harp, D., Bachmann, I., \& Loke, J. (2014). Where Are the Women? The Presence of Female Columnists in US Opinion Pages. Journalism \& Mass Communication Quarterly, 91(2), 289-307.

Hindman, E. B., \& Thomas, R. J. (2013). Journalism's "crazy old aunt": Helen thomas and paradigm repair doi:10.1177/1077699013482909

Laughlin, K. A., \& Castledine, J. (Eds.). (2012). New Directions in American History: Breaking the Wave. Florence, KY, USA: Routledge. Retrieved from http://www.ebrary.com

Lipton, J. (2001). Barbara walters. Columbia Journalism Review, 40(4), 80. Retrieved from http://search.ebscohost.com.www.libproxy.wvu.edu/login.aspx?direct=true $\& d b=a 9$ h\&AN=5527144\&site $=$ ehost-live

Lutes, J. M. (2003). Sob sisterhood revisited. American Literary History, 15(3), 504-532. doi:10.1093/alh/ajg031 
Mann, S. A., \& Huffman, D. J. (2005). The decentering of second wave feminism and the rise of the third wave. Science \& Society, 69(1, Marxist-Feminist Thought Today), 56-91. Retrieved from http://www.jstor.org/stable/40404229

Mayring, Philipp (2000). Qualitative Content Analysis [28 paragraphs]. Forum Qualitative Sozialforschung / Forum: Qualitative Social Research, 1(2), Art. 20, http://nbnresolving.de/urn:nbn:de:0114-fqs0002204

McPherson, James Brian (2006). Journalism at the end of the american century (1965-present). Westport, Conn.: Praeger.

Murphy, Julien S. (1999). Feminist interpretations of jean-paul sartre. University Park, PA: Pennsylvania State University Press.

Olson, C. C. (2012). The morning cheerleader and the news quarterback: The failure to frame female news anchors. Media Report to Women, 40(4), 6-21. Retrieved from http://search.ebscohost.com.www.libproxy.wvu.edu/login.aspx?direct=true \&db=a9 h\&AN=84380509\&site $=$ ehost-live

Painter, C., \& Ferrucci, P. (2012). Unprofessional, ineffective, and weak: A textual analysis of the portrayal of female journalists on sports night. Journal of Mass Media Ethics, 27(4), 248-262. doi:10.1080/08900523.2012.746107

Pay equity overview. (2014). Congressional Digest, 93(5), 3-32. Retrieved from http://search.ebscohost.com.www.libproxy.wvu.edu/login.aspx?direct=true $\& d b=a 9$ h\&AN=95883184\&site=ehost-live 
Rehak, M. (2005). Girl sleuth: Nancy Drew and the women who created her. Orlando: Harcourt. Reed v. Reed, 404 U.S. 71 (1971). Retrieved from

http://caselaw.lp.findlaw.com/scripts/getcase.pl?court=US\&vol=404\&invol=71

Roe v. Wade, 410 U.S. 113 (1973). Retrieved from http://caselaw.lp.findlaw.com/scripts/getcase.pl?court=US\&vol=410\&invol=113

Rose, B. (1980). Mass mediated images: The force of television in the china syndrome. Journal of Popular Film \& Television, 8(3), 2-9. Retrieved from http://search.ebscohost.com.www.libproxy.wvu.edu/login.aspx?direct=true\&db=f3h\&AN $=31140459 \&$ site $=$ ehost-live

Russlynn, Ali (2011). Dear Colleague Letter from Assistant Secretary for Civil Rights, United States Department of Education, 1. Retrieved April 6, 2015, from http://www2.ed.gov/about/offices/list/ocr/letters/colleague-201104.html

Saltzman, J. (2002). Frank capra and the image of journalists in american film. USA Today Magazine, 131(2690), 54. Retrieved from http://search.ebscohost.com.www.libproxy.wvu.edu/login.aspx?direct=true\&db=a9h\&A $\mathrm{N}=7831375 \&$ site $=$ ehost-live

Sartre, Jean-Paul Sartre. (1957). Existentialism and Human Emotions. New York: Citadel Press.

The second wave of feminism. (2014). In Encyclopaedia Britannica Online. Retrieved from http://www.britannica.com/women/article-216008 
Singer, Daniel (2000). Sartre's roads to freedom. The nation. Retrieved from http://web.archive.org/web/20080602061137/http://www.thenation.com/doc/20000605/si nger/single

Sistiaga, Jon (2004). Ninguna guerra se parece a otra. Barcelona: Mondadori.

Smith, D. W. (2013) Phenomenology. In The Stanford Encyclopedia of Philosophy. Retrieved from http://plato.stanford.edu/archives/win2013/entries/phenomenology/

United States Equal Employment Opportunity Commission. Equal Pay Act of 1963. Vol. 29. (1963, June 10). United States Code. Retrieved from http://www.eeoc.gov/eeoc/history/35th/thelaw/epa.html

United States Equal Employment Opportunity Commission. Title IV of the Civil Rights Act of 1964. (1964). United States Code. Retrieved from http://www.eeoc.gov/laws/statutes/titlevii.cfm.

Valencia, O. B., Cantalapiedra, M. J., García, C. C., Arratibel, A. G., Fernández, S. P., \& Dasilva, J. Á. P. (2008). ... So what? she's A newspaperman and she's pretty. women journalists in the cinema. Zer: Revista De Estudios De Comunicacion, 13(25), 221-242.

Wang, S. (2006). Human incompletion, happiness, and the desire for god in sartre's being and nothingness. Sartre Studies International, 12(1), 1-17. doi:10.3167/135715506780646213

Weiler, K. (2008). The feminist imagination and educational research. Discourse: Studies in the Cultural Politics of Education, 29(4), 499-507. doi:10.1080/01596300802410219

Who We Are. (n.d.). Retrieved from http://now.org/about/who-we-are/ 


\section{Appendix}

Portrayals of Female Journalists Before and After the Second-Wave Feminism Movement

\section{Content Analysis - Coding Sheet}

Coder:

Date:

Film:

Male

Female

Film Release: Month:

Day:

Year:

1. Film Length: Short (60 minutes or less)

Medium (more than 60 minutes and 90 minutes or less )

Long (more than 90 minutes)

2. Film Studio:

Columbia

Warner Brothers

$20^{\text {th }}$ Century Fox

Metro-Goldwyn-Mayer

3. Gender of Director: Male

Female 
4. Relationship Status of Female Journalist at Beginning of Film

Single
Dating
Married
Divorced

5. Relationship Status of Female Journalist at End of Film

Single
Dating
Married
Divorced

6. Does the female journalist have children? Yes

No

7. Does the female journalist portray the "sob sister" persona? (The term was coined to describe "a female journalist who specialized in sentimental or human-interest stories, or more generally, a woman writer "who could wring tears"' (Lutes, 2003, p. 504).)

$$
\text { Yes }
$$

No 
8. Second-Wave Feminism Movement (Gordon (2013) also stated that second-wave feminism lasted "from the mid-1960s to its decline in momentum in the 1980s" (p. 21).)

Before

During/After the Decline

9. In which journalism field does the female journalist work?

Print

Television

Radio

10. For which type of media outlet does the female journalist work?

Tabloid

Entertainment

Political

News

Feature

11. What position(s) does the female journalist hold?

Reporter

Anchor

Director

Producer

Editor 
12. Does the female journalist appear to advance her career during the film? Yes

No 